\title{
UJI TOKSISITAS FRAKSI n-BUTANOL BERUWAS LAUT (Scaevola taccada (Gaertn.) Roxb.) DENGAN METODE BRINE SHRIMP LETHALITY TEST
}

\author{
Irma Santi, Sitti Nurbaezurah \\ Fakultas Farmasi Universitas Muslim Indonesia \\ Email :Irma_UMI01@yahoo.com
}

\begin{abstract}
The research on Toxicity Test Of n-Butanol Fraction Beruwas Laut (Scaevola taccada (Gaertn.) Roxb.) Using Brine Shrimp Lethality Test Method an investigation with larvaes Artemia salina Leach as test animal which is intended to potential toxic test. Each treatment is done the replication of research 3 times of the fraction $n$ butanol beruwas laut concentration are $0,1 \mu \mathrm{g} / \mathrm{ml}, 1 \mu \mathrm{g} / \mathrm{ml}, 10 \mu \mathrm{g} / \mathrm{ml}, 100 \mu \mathrm{g} / \mathrm{ml}$ and solvent control $n$-butanol by same concentration. The result is against larvae that died 24 hours after component test was given. Through the data, $L C_{50}$ value of n-butanol fraction Beruwas Laut (Scaevola taccada (Gaertn.) Roxb.) was analyzed by probit analysis. This research indicated concentration of fraction $n$-butanol of beruwas laut (Scaevola taccada (Gaertn.) Roxb.) could kill larvae by the concentration of $0,1 \mu \mathrm{g} / \mathrm{ml}, 1 \mu \mathrm{g} / \mathrm{ml}, 10 \mu \mathrm{g} / \mathrm{ml}$ and $100 \mu \mathrm{g} / \mathrm{ml}$. The result of probit analysis indicated that $L C_{50}$ value of fraction Beruwas Laut of (Scaevola taccada (Gaertn.) Roxb.) was 12,16 $\pm 11,23 \mu \mathrm{g} / \mathrm{mL}$. Research result and probit analysis indicated that $n$-butanol fraction of beruwas laut (Scaevola taccada (Gaertn.) Roxb.) toxic characteristic by $L C_{50}$ value was $12,16 \pm 11,23 \mu \mathrm{g} / \mathrm{ml}$. On according Meyer test result explained toxic about Artemia salina Leach when extract had $L C_{50}$ less of $1000 \mu \mathrm{g} / \mathrm{mL}$.
\end{abstract}

Key Words : Toksisitas Test, n-butanol Scaevola taccada (Gaertn.)Roxb), Brine Shrimp Lethality Test

\section{PENDAHULUAN}

Belakangan ini telah banyak penelitian yang bersumber dari tanaman. Salah satu tanaman tradisional yang diteliti adalah Beruwas Laut (Scaevola taccada (Gaertn.) Roxb.) sebagai obat infeksi mata, menyembuhkan gangguan pencernaan, malaria, batuk dan flu. Sampai saat ini belum banyak penelitian yang membahas tentang toksisitas beruwas laut (Scaevola taccada (Gaertn.) Roxb.) (Wardini, 2011).

Sifat toksisitas dari suatu senyawa dapat diasosiasikan sebagai aktifitas antikanker, namun dalam metode Brine Shrimp Lethality Test ini tidak spesifik untuk mendeteksi senyawa antikanker. Oleh karena itu, setelah uji toksisitas dengan menggunakan Brine Shrimp lethality 
Test perlu dilakukan uji sitotoksisitas. Sehingga uji dengan metode BST ini merupakan uji awal untuk mengetahui senyawa yang memiliki potensi atau tidak sebagai antikanker.

\section{Metode "Brine Shrimp Lethality}

Test" merupakan langkah pertama untuk uji toksisitas ekstrak atau senyawa. Metode ini merupakan metode uji hayati yang sederhana, cepat, murah, dan dapat dipercaya. Daya toksisitas suatu senyawa dapat diketahui dengan menghitung jumlah kematian larva Artemia salina Leach dengan parameter Lethal Concentration 50 ( $\left.\mathrm{LC}_{50}\right)$. Suatu ekstrak dinyatakan bersifat toksik menurut metode "Brine Shrimp Lethality Test" menunjukkan bahwa ekstrak tumbuhan bersifat toksik maka dapat dikembangkan ke penelitian yang lebih lanjut untuk mengisolasi senyawa sitotoksik tumbuhan sebagai usaha pengembangan obat alternative antikanker (Rosenda,2009).

\section{METODE PENELITIAN}

\section{A. Bahan dan Alat}

Alat-alat yang digunakan dalam penelitian ini adalah aerator (Life $Q_{3}$ ), lampu, mikropipet (Mikropipetman), Rotavapor ( IKA rv 10 ), seperangkat alat gelas, seperangkat alat maserasi, timbangan kasar (O'hauss), timbangan analitik dan vial.

Bahan-bahan yang digunakan dalam penelitian ini adalah air laut, aquadest, fraksi nbutanol beruwas laut (Scaevola taccada(Gaertn.) Roxb.), etanol 70 $\%$, n-Butanol jenuh air, ragi, dan telur udang (Artemia salina Leach).

\section{B. Prosedur Kerja}

\section{Penyiapan Sampel}

\section{a. Pengambilan sampel}

Sampel beruwas laut (Scaevola taccada (Gaertn.) Roxb.) diambil dari Cappa Batue Kelurahan Wiring Tasi Kecamatan Suppa Kabupaten Pinrang Provinsi Sulawesi-Selatan.

\section{b. Pengolahan sampel}

Sampel beruwas laut (Scaevola taccada (Gaertn.) Roxb.) dicuci bersih dengan menggunakan air yang mengalir, kemudian dipotong-potong kecil dan dikeringkan dengan cara diangin-anginkan dan tidak terkena sinar matahari langsung.

\section{Ekstraksi Sampel}

\section{a. Ekstraksi secara maserasi dengan pelarut etanol}


Sampel beruwas laut (Scaevola taccada (Gaertn.) Roxb.) yang telah dikeringkan, ditimbang sebanyak 300 gram kemudian dimasukkan ke dalam wadah maserasi. Ditambahkan etanol $70 \%$ hingga simplisia tersebut terendam seluruhnya sebanyak 5 liter dan dibiarkan selama 5 hari dengan pengadukan beberapa kali. Ekstrak cair yang diperoleh diuapkan dengan menggunakan rotavapor hingga diperoleh ekstrak etanol kental.

b. Ekstraksi dengan pelarut n-butanol jenuh air

Ekstrak etanol yang diperoleh kemudian dipartisi cair-cair menggunakan pelarut n-butanol jenuh air. Ekstrak etanol kental ditimbang sebanyak 10 gram kemudian disuspensikan dengan air sebanyak $15 \mathrm{ml}$ kemudian dimasukkan ke dalam corong pisah dan ditambahkan dengan nbutanol jenuh air, dikocok sampai merata dan didiamkan sampai terjadi pemisahan dari fase air dan fase n-butanol, dipisahkan fase air dan fase n-butanol kemudian fase air dimasukkan kembali ke dalam corong pisah dan dipartisi lagi dengan nbutanol jenuh air dan dilakukan hingga jernih. Fraksi n-butanol yang diperoleh dari beberapa kali penyaringan disatukan kemudian diuapkan sampai mendapatkan fraksi.

\section{Penyiapan Larva}

Sebanyak $50 \mathrm{~g}$ telur udang Artemia salina Leach, direndam dalam wadah yang berisi $200 \mathrm{ml}$ air laut pada kondisi $\mathrm{pH} 7$ dibawah cahaya lampu dan dilengkapi dengan aerator pada suhu $25^{\circ} \mathrm{C}$. Telur udang akan menetas setelah 24 jam dan menjadi larva setelah berumur 2 hari (48 jam).

\section{Pelaksanaan Pengujian}

Fraksi n-butanol kental ditimbang sebanyak $100 \mathrm{mg}$ dilarutkan dengan n-butanol 10 $\mathrm{ml}$ sehingga diperoleh konsentrasi $100 \mathrm{mg} / 10 \mathrm{ml}$ sebagai larutan persediaan (stok). Dari sediaan tersebut 
dipipet $0,1,1,10$, dan 100 $\mu \mathrm{g} / \mathrm{ml}$ ke dalam vial, lalu diuapkan. Untuk kontrol yaitu pelarut n-butanol (10 $\mu \mathrm{L} \quad \mathrm{n}$ butanol dalam $10 \mathrm{ml}$ air laut) kemudian dipipet $0,1,1,10$, dan $100 \mu \mathrm{L} / \mathrm{ml}$ ke dalam masingmasing vial dan ditambahkan 5 $\mathrm{ml}$ air laut. Lalu dimasukkan 10 ekor larva udang Artemia salina Leach, dan dicukupkan volumenya sampai $10 \mathrm{ml}$. Tiap vial ditambahkan 1 tetes suspensi ekstrak ragi ( $3 \mathrm{mg}$ dalam $5 \mathrm{ml}$ air laut) sebagai sumber makanan. Vial-vial uji kemudian disimpan ditempat yang cukup mendapat sinar lampu. Setelah 24 jam dilakukan pengamatan terhadap jumlah larva yang mati. Untuk tiap sampel dan kontrol dilakukan pengulangan sebanyak 3 kali.

HASIL PENELITIAN

\begin{tabular}{ccccc}
\hline \multirow{2}{*}{ Jenis Sampel } & \multicolumn{5}{c}{$\begin{array}{c}\text { Jumlah larva udang yang mati tiap } \\
\text { konsentrasi }(\boldsymbol{\mu g} / \mathbf{m l})\end{array}$} \\
\cline { 2 - 5 } & $\mathbf{0 , 1}$ & $\mathbf{1}$ & $\mathbf{1 0}$ & $\mathbf{1 0 0}$ \\
\hline \multirow{2}{*}{ Fraksi n-Butanol } & 3 & 4 & 5 & 8 \\
& 2 & 4 & 6 & 6 \\
\hline Total kematian & 2 & 4 & 5 & 7 \\
\hline$\%$ kematian & 7 & 12 & 16 & 21 \\
\hline Pembanding n-Butanol & $23,33 \%$ & $40 \%$ & $53,33 \%$ & $70 \%$ \\
\hline Total kematian & 0 & 0 & 0 & 0 \\
\hline$\%$ kematian & 0 & 0 & 0 & 0 \\
\hline & 0 & 0 & 0 & 0 \\
\hline
\end{tabular}

\section{PEMBAHASAN}

Brine Shrimp Lethality Test (BST) adalah suatu metode pengujian dengan menggunakan hewan uji yaitu Artemia salina Leach, yang dapat digunakan sebagai bioassay yang sederhana untuk meneliti toksisitas akut suatu senyawa, dengan cara menentukan nilai LC 50 yang dinyatakan dari komponen aktif suatu simplisia maupun bentuk sediaan ekstrak dari suatu tanaman. Apabila suatu ekstrak tanaman bersifat toksik menurut harga LC 50 dengan metode BSLT, maka tanaman tersebut dapat dikembangkan sebagai obat anti kanker. Namun, bila tidak bersifat toksik maka tanaman tersebut dapat diteliti kembali untuk mengetahui khasiat lainnya dengan menggunakan hewan coba lain yang lebih besar dari larva Artemia salina Leach seperti mencit dan tikus secara in vivo. Pada penelitian ini dilakukan pengujian 
toksisitas fraksi n-butanol beruwas laut (Scaevola taccada (Gaertn.) Roxb.) dengan ditimbang fraksi n-butanol kental ditimbang sebanyak $100 \mathrm{mg}$ dilarutkan dengan n-butanol $10 \mathrm{ml}$ sehingga diperoleh konsentrasi 100 $\mathrm{mg} / 10 \mathrm{ml}$ sebagai larutan persediaan (stok). Dari sediaan tersebut dipipet $0,1,1,10$, dan $100 \mu \mathrm{g} / \mathrm{ml}$ ke dalam vial, lalu diuapkan. Untuk kontrol yaitu pelarut n-butanol (10 $\mu \mathrm{L}$ n-butanol dalam $10 \mathrm{ml}$ air laut) kemudian dipipet $0,1,1,10$, dan $100 \mu \mathrm{L} / \mathrm{ml}$ ke dalam masing-masing vial dan ditambahkan $5 \mathrm{ml}$ air laut. Lalu dimasukkan 10 ekor larva udang Artemia salina Leach, dan dicukupkan volumenya sampai $10 \mathrm{ml}$. Tiap vial ditambahkan 1 tetes suspensi ekstrak ragi ( $3 \mathrm{mg}$ dalam $5 \mathrm{ml}$ air laut) sebagai sumber makanan. Vial-vial uji kemudian disimpan ditempat yang cukup mendapat sinar lampu. Setelah 24 jam dilakukan pengamatan terhadap jumlah larva yang mati. Untuk tiap sampel dan kontrol dilakukan pengulangan sebanyak 3 kali.

Metode ekstraksi yang digunakan adalah maserasi karena tekstur tanaman yang digunakan lunak. Maserasi merupakan cara penyarian sederhana, yang dilakukan dengan cara merendam simplisia dalam cairan penyarian. Metode maserasi digunakan untuk menyari simplisia yang mengandung zat aktif atau komponen kimia yang mudah larut dalam cairan penyari. Proses maserasi digunakan cairan penyari pelarut etanol yang bersifat semipolar untuk menarik komponen-komponen kimia yang bersifat polar maupun nonpolar. Hal ini dilakukan karena belum diketahui komponen kimia yang diduga mempunyai aktivitas yang besar terhadap larva udang Artemia salina Leach yang digunakan sebagai parameter ketoksikan.

Penelitian ini digunakan variasi konsentrasi $0,1,1,10$, dan $100 \mu \mathrm{g} / \mathrm{mL}$ dengan pembanding pelarut $\mathrm{n}$-butanol dengan konsentrasi yang sama dimaksudkan untuk melihat variasi respon kematian hewan uji yang disebabkan dari sampel dan bukan dari pelarutnya.

Hewan uji yang digunakan larva udang yang berumur 48 jam karna pada umur 48 jam larva telah lepas dari cangkang telurnya dan pertumbuhannya sangat cepat serta daya tahan hidupnya yang baik sehingga dapat digunakan untuk uji ketoksikan.

Selama pengamatan dikondisikan pada $\mathrm{pH}$ 7-8 sama dengan $\mathrm{pH}$ air laut yang merupakan $\mathrm{pH}$ penetasan yang optimum serta 
pemberian oksigen dengan menggunakan aerator dalam penetasan larva yang dimaksudkan untuk membantu sirkulasi oksigen yang dibutuhkan tercukupi dan pemberian sinar lampu yang cukup pada suhu $25^{\circ} \mathrm{C}$ untuk merangsang penetasan telur. Pemberian makan dilakukan pada saat penetasan larva pada umur 48 jam dengan 1 tetes suspensi ragi sebagai sumber makanan bagi larva.

Suatu senyawa dinyatakan mempunyai potensi toksisitas akut jika mempunyai harga $\mathrm{LC}_{50}$ kurang dari $1000 \mu \mathrm{g} / \mathrm{ml}$. LC 50 (Lethal Concentration 50) merupakan konsentrasi zat yang menyebabkan terjadinya kematian pada $50 \%$ hewan uji yaitu larva Artemia salina Leach. Pengujian terhadap fraksi n-butanol beruwas laut menunjukkan harga $L_{50}$ sebesar $12,16 \pm 11,23 \mu \mathrm{g} / \mathrm{mL}$, sehingga dapat dikatakan bahwa fraksi n-butanol beruwas laut pada pengujian ini memiliki potensi toksik terhadap hewan uji larva Artemia salina Leach, maka tanaman tersebut dapat dikembangkan dan dilanjutkan penelitiannya sebagai obat anti kanker.

\section{KESIMPULAN}

Hasil penelitian dan hasil analisis probit yang dilakukan dapat disimpulkan bahwa fraksi n-butanol beruwas laut (Scaevola taccada (Gaertn.) Roxb.) bersifat toksik dengan nilai LC $_{50}$ sebesar $12,16 \pm 11,23$ $\mu \mathrm{g} / \mathrm{mL}$.

\section{DAFTAR PUSTAKA}

Anderson,.J.E.,Goetz,C.M,. $1991 . \quad A$ Blind Comparison Of Simple Benzch Top Bioassay And Human Tumor Cell Cytotoxicities As Antitumor Prescreens, phytochem.Anal., volume 2.

Casarett,L.J., dan Doul J. 1975. Toxicology, The Basic Sceine of Poison, First Edition, Mac Millan Publishing, Co, Inc, Newyork.

Ditjen POM., 1986. Sediaan Galenik. Jakarta : Departemen Kesehatan Republik Indonesia, Jakarta.

Donatus IG, Makhfoel D. 1990. Toksin Pangan. Yogyakarta: PAU UGM.

Loomis,T.A., 1978. Toksisitas Dasar, edisi III, penerjemah Imono Argo, IKIP Semarang Press.

Maysatria Yamato, 2011. Scaevola taccada (Online), (http:// muherda. blogspot. com/ 2011/02/scaevola-taccada. html, Diakses 22 Maret 2012)

Meyer,B.N.,Ferrigni,N.R.,Putman,J.E., Jacbsen,L.B.,Nicols,.D.E., and Mclaughlin,J.L. 1982. Brine Shrimp :A Comvenient general Bioassay For Active Plant Constituents.Plant Medica.

Mudjiman, A.1989. Udang Renik Air Asin. Brata Karya Aksara, Jakarta. 
Mukono, H. J. 2005. Toksikologi Lingkungan. Airlangga University Press, Surabaya.

Mc Laughlin, J.E. 1998. A Blind Coparison of Simple Bench-top Bioassay and Human Tumor Cel Citotoxicities es AntiTumor Prescreens. Natural Product Chemistry, Elsvier, Amsterdam.

National Tropical Botanical Garden. 2011. Scaevola taccada (Online). http://ntbg.org/plants/scaevolatac cada/plantdetails.php.htm, Diakses 20 Maret 2012)

Ong Hean Chooi, 2004, Tumbuhan Liar : Khasiat Obat Dan Kegunaan (Online), http: //www. scribd.com/doc/64909444/BioDivers-It-As , Diakses 22 Maret 2012).

Parwati, T. dan P. Simanjuntak, 1998. Daya toksik beberapa tumbuhan obat tradisional Indonesia asal Nusa Tenggara Barat. Journal Biologi Indonesia.

Pujiati, I., S. Ningsih, S. Palupi dan Tri Windono, 2002. Uji toksisitas terhadap larva Artemia salina Leach dari fraksi n-heksan, khloroform, etil asetat dan air ekstrak etanol rimpang temumangga (Curcuma mangga VaL). Prosiding Seminar Nasional Tumbuhan Obat Indonesia XXI. Universitas Surabaya, Surabaya.

Pryanto, Drs. Apt. 2009. Toksikologi Mekanisme, Terapi Antidotum dan Penelitian Resiko. Lembaga Studi dan Konsultasi Farmakologi (Leskonfi). Depok.

Rauf, Maryani. 2012. Aktivitas Antimikroba Ekstrak n-Heksan Daun Beruwas Laut (Scaevola taccada (Gaertn.)Roxb.) Dengan Metode KLT-Bioautografi. Fakultas Farmasi. Universitas Muslim Indonesia.

Rosenda, E.H. Anandita dan Suhardjono. 2009. Uji Toksisitas Ekstrak Etanol Daun Kemangi (Ocimun sanctum Linn). Terhadap Larva Artemia salina Leach Dengan Metode Brine Shrimp Lethality Test (BST). Majalah Faramasi Indonesia, Semarang.

Soemirat, Juli. Dkk. 2009. Toksikologi Lingkungan. Gadja Mada University Press, Yogjakarta.

Soo, S.Y. 2009. Medical Plants In Papua New Guinea. Western Pacific: WHO Press.

Tobo, F. 2001. Buku Pengantar Laboratorium Fitokimia $I$. Laboratorium Fitokimia Jurusan Farmasi Fakultas MIPA Universitas Hasanuddin, Makassar.

Wardini, T. H., 2011. Medicinal and Poisonous Plants (Online) (http://www.proseanet.org/florakit a/browser. .php?docsid $=747$ Diakses 20 Maret 2012) 